Japan. J. Med. Sci. Biol., 41, 49-56, 1988.

\title{
PRODUCTION OF A FACTOR INHIBITING TUMOR CELL MIGRATION BY SPLEEN CELLS FROM TUMOR-BEARING MICE
}

\author{
Ivan RAICHEV and Raina DOTCHEVSKA
}

Department of Pathology, Pleven University School of Medicine, Pleven 5800, Bulgaria

(Received August 17, 1987. Accepted August 1,1988)

SUMMARY: A factor inhibiting tumor cell migration was found in the culture supernatants of spleen cells of BALB/c mice transplanted with sarcoma cells 20 days before or injected with killed sarcoma cells 14 days before, when the spleen cells were stimulated in vitro for 2 or $24 \mathrm{hr}$ with a $3 \mathrm{M} \mathrm{KCl}$ extract of the sarcoma. This factor did not inhibit the migration of guinea-pig macrophages or of theophylline-pretreated sarcoma cells. When the supernatants were fractioned on Sephadex G-100 columns, active fractions with molecular weights lower than 14,000 were distributed broadly.

\section{INTRODUCTION}

Murine lymphoma cells and Burkitt's lymphoma cells can migrate out of capillary tubes $(1,2)$. Supernatants containing tumor migration-inhibition factor (TMIF) have been obtained from different human lymphoid cell lines and concanavalin A-stimulated murine lymphocyte cultures (3). This factor has been found to be distinct from both the macrophage migration-inhibition factor and leukocyte-inhibitory factor (4). The recent work by Donskoy et al. (5) has demonstrated that TMIF can inhibit the migration of tumor cells derived from a methylcholanthrene-induced fibrosarcoma as well as P815 mastocytoma and Ehrlich tumor.

The purpose of this study is to determine whether the spleen lymphocytes from mice transplanted or immunized with tumor cells produce a factor inhibiting the migration of tumor cells in vitro, when stimulated with the tumor-associated antigen. 


\section{MATERIALS AND METHODS}

Animals: Inbred male BALB/c mice, 10-12 weeks old ,were obtained from the production colonies of the Bulgarian Academy of Sciences.

Tumors: A sarcoma was induced in a BALB/c mouse by an injection of $1 \mathrm{mg}$ of 20-methylcholanthrene, and has been maintained by serial sc transplantations of small pieces of tumor in syngeneic mice. Histologically this sarcoma was a poorly differentiated fibrosarcoma. Ehrlich ascites tumor has been maintained by serial ip transplantations $\left(1 \times 10^{6}\right.$ cells $)$ every 10 days in BALB/c mice.

Tumor-bearing mice: Mice carrying sarcomas of the 4th to 16th passage generations were used as the tumor bearers. The tumor-bearing mice were killed 20 days after the transplantation.

Tumor cells: Cell suspensions were prepared from finely minced solid sarcomas by treatment with $0.3 \%$ collagenase (Sigma Chemical Co., St. Louis, MO) containing $10 \mu \mathrm{g} / \mathrm{ml}$ DNase at $37 \mathrm{C}$ for $30 \mathrm{~min}$, and were then passed through a steel sieve. The cells were washed twice in Hanks' balanced salt solution and resuspeded in RPMI 1640 (GIBCO) containing $5 \%$ heat-inactivated fetal calf serum (FCS) at a concentration of $2 \times 10^{7}$ cells $/ \mathrm{ml}$.

Immunization of mice: For immunizing mice, sarcoma cells stored in a freezing state at - $-20 \mathrm{C}$ were heated at $56 \mathrm{C}$ for $30 \mathrm{~min}$ and emulsified in Freund's incomplete adjuvant. Each mouse was injected subcutaneously with the cells $(6 \times$ 106 cells in total) into the inguinal regions and the hind paws. The inoculation was repeated 7 days later. The immunized mice were killed 14 days after the second immunization.

Preparation of spleen cells: Spleen cell suspensions were prepared in RPMI 1640 (GIBCO) supplemented with $5 \%$ FCS, penicillin $(100 \mathrm{IU} / \mathrm{ml})$, and streptomycin $(100 \mathrm{\mu g} / \mathrm{ml})$. The suspensions were freed of erythrocytes by treatment with cold distilled water for $30 \mathrm{sec}$ and adjusted to a final concentration of $20 \times 106 \mathrm{cells} / \mathrm{ml}$. A T-lymphocytes-rich fraction was obtained by filtration on a nylon wool column as described by Julius et al (6).

Preparation of the sarcoma extract: Ten milliliters of cold $3 \mathrm{M} \mathrm{KCl}$ prepared in PBS ( $\mathrm{pH} 7.2$ ) was added to every $1 \mathrm{~g}$ of tumor pieces which corresponded to $3 \times$ 108 sarcoma cells. The mixture was shaken at $4 \mathrm{C}$ for $16 \mathrm{hr}$ and then centrifuged at $160,000 \times \mathrm{g}$ for $1 \mathrm{hr}$ at $4 \mathrm{C} \mathrm{(7).} \mathrm{Further} \mathrm{centrifugation} \mathrm{of} \mathrm{the} \mathrm{mixture} \mathrm{was} \mathrm{done} \mathrm{at}$ $40,000 \times g$ and at $18,000 \times g(8,9)$. The supernatants were dialyzed against PBS for $24 \mathrm{hr}$, and protein content was determined by Lowry's method. It was adjusted to $0.25-0.28 \mathrm{mg}$ protein $/ \mathrm{ml}$, and designated as the sarcoma extract.

Stimulation of spleen cells with the sarcoma extract: Four-tenth milliters of a spleen cell suspension was mixed with $0.2 \mathrm{ml}$ of the sarcoma extract, and the mixture was incubated at $37 \mathrm{C}$ in an atmosphere of $5 \% \mathrm{CO}_{2}$ for 2 or $24 \mathrm{hr}$ and centrifuged at $18,000 \times \mathrm{g}$ for $20 \mathrm{~min}$ at $4 \mathrm{C} \mathrm{(10).} \mathrm{The} \mathrm{supernatant} \mathrm{was} \mathrm{dialyzed}$ against $0.15 \mathrm{M} \mathrm{NaCl}$ and distilled water, and then concentrated to $0.4-0.6 \mathrm{mg}$ of 
protein per $\mathrm{ml}$. It was irradiated with ultraviolet light and stored at $-25 \mathrm{C}$ until use.

Fractionation on Sephadex G-100 columns: The supernatant of the spleen cells incubated with the tumor extract for $2 \mathrm{hr}$ was further concentrated to 1-1.5 $\mathrm{mg}$ of protein per $\mathrm{ml}$, and then fractioned by gel chromatography on a $10 \times 700$ $\mathrm{mm}$ column containing Sephadex G-100 up to $640 \mathrm{~mm}$. For the eluant solution, $0.15 \mathrm{M} \mathrm{NaCl}$ was used. Flow rate was $28 \mathrm{ml} / \mathrm{hr}$. The following mol.wt. markers were used: human-plasma albumin with mol.wt. of 66,500 daltons, peroxidase (E. Merck, mol.wt. $=40,000$ daltons), cytochrom C (Biomed, Krakow, mol.wt. $=14,000$ daltons) and Komb-Insulin S (Hoechst AG, mol.wt. $=5,800$ daltons). The extinctions of the eluting material were recorded at $280 \mathrm{~nm}$ on a VSU-2 spectrophotometer (DDR).

Assessment of migration inhibition: Samples of $0.2 \mathrm{ml}$ of the target cells suspended in RPMI 1640 supplemented with 5\% FCS and antibiotics which contained $2 \times 10^{7}$ cells per $\mathrm{ml}$ were mixed with $0.1 \mathrm{ml}$ of the supernatant of spleen cells stimulated by the sarcoma extract or with its fractions. They were incubated for $2 \mathrm{hr}$ at $37 \mathrm{C}$ in a $5 \% \mathrm{CO}_{2}$ atmosphere. As the target cells, sarcoma cells prepared from solid transplanted tumors, Ehrlich ascites tumor cells, guinea-pig macrophages (peritoneal exudate cells) and theophylline-treated sarcoma cells (see below) were employed. Capillary tubes sealed at one end were filled with either of the target cells, centrifuged at $250 \times g$ and the portions with the sedimented cells were cut off. The tubes were then placed in chambers filled with medium and incubated at $37 \mathrm{C}$ for $24 \mathrm{hr}$. The areas of target-cell migration were measured by planimetry. The migration index (MI) was calculated according to the following formula:

$$
\begin{aligned}
& \text { Average area of migration of target cells incubated }
\end{aligned}
$$

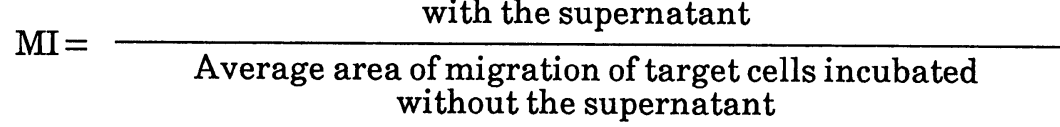

MI less than 0.80 was considered as significant.

A culture supernatant of spleen cells incubated without the sarcoma extract for $2 \mathrm{hr}$ and then reconstituted with the extract was taken as a control. Normal spleen cells were also employed as a control.

Treatment of sarcoma cells with theophylline: The procedure used for separating T-lymphocytes into theophylline-resistant $\left(\mathrm{T}_{\mathrm{R}}\right)$ and theophyllinesensitive $\left(\mathrm{T}_{\mathrm{S}}\right)$ subsets was applied $(11,12)$. Briefly, equal volumes of a tumor cell suspension $\left(10 \times 106 / \mathrm{ml}\right.$ in RPMI 1640) and a solution of theophylline $\left(10^{-3} \mathrm{M}\right.$ in $\mathrm{PBS}, \mathrm{pH} 7.2$ ) were mixed and the mixture was incubated for $60 \mathrm{~min}$ at $37 \mathrm{C}$. Then the cells were washed twice with the medium and used as the theophylline-treated cells. 
Cell differentiation staining and electron microscopy: The smears from sedimented spleen cells were fixed in methyl alcohol and stained by Giemsa method. Ribonucleic acid was stained with methylgreen pyronin.

For electron microscopy, spleen cells were fixed in $1.6 \%$ glutaraldehyde in 0.1 $\mathrm{M}$ phosphate buffer ( $\mathrm{pH} 7.4$ ), postfixed in $1 \%$ osmium tetroxide, dehydrated with ethanol and embedded in Durcopen.

Statistics: The variational analysis and the Student's $t$ test were performed for testing for significance of the values obtained.

\section{RESULTS}

MI of sarcoma cells incubated with various culture supernatants of spleen cells obtained from sarcoma-bearing, sarcoma-immunized or normal mice are shown in Table I. The culture supernatants of spleen cells from either the

Table I. Inhibition of sarcoma-cell migration by culture supernatants of spleen cells with or without stimulation with the $3 \mathrm{M} \mathrm{KCl}$ extract of sarcoma

\begin{tabular}{lcl}
\hline Spleen cells from & $\begin{array}{l}\text { Incubation } \\
\text { period (hr) with } \\
\text { tumor extract }\end{array}$ & $\begin{array}{l}\text { Migration } \\
\text { index( } \pm \mathrm{SD})\end{array}$ \\
\hline Sarcoma-bearing mice & No & $0.92 \pm 0.10$ \\
Immunized mice & No & $0.84 \pm 0.09$ \\
Normal mice & 2 & $0.87 \pm 0.09$ \\
Sarcoma-bearing mice & 2 & $0.61 \pm 0.08$ \\
Immunized mice & 2 & $0.55 \pm 0.09$ \\
Sarcoma-bearing mice & 24 & $0.47 \pm 0.08$ \\
Immunized mice & 24 & $0.42 \pm 0.07$ \\
\hline
\end{tabular}

Spleen cells from sarcoma-bearing mice or mice immunized with the tumor cells were incubated with or without the $3 \mathrm{M} \mathrm{KCl}$ tumor extract. Two or $24 \mathrm{hr}$ after incubation at $37 \mathrm{C}$, the mixtures were centrifuged, and MI of the supernatants were measured with the sarcoma cells as target. 
Table II. Migration inhibition of various target cells by culture supernatants of spleen cells stimulated with the $3 \mathrm{M} \mathrm{KCl}$ extract of sarcoma

\begin{tabular}{lcl}
\hline Spleen cells from & Target cells & Migration index \\
\hline Sarcoma-bearing mice & Sarcoma cells & $0.66 \pm 0.06$ \\
Sarcoma-bearing mice & $\begin{array}{c}\text { Theophylline- } \\
\text { treated sarcoma cells }\end{array}$ & $1.12 \pm 0.13$ \\
Sarcoma-bearing mice & Ehrlich cells & $0.60 \pm 0.06$ \\
Immunized mice & Ehrlich cells & $0.62 \pm 0.07$ \\
Sarcoma-bearing mice & Macrophages & $0.88 \pm 0.09$ \\
Immunized mice & Macrophages & $0.94 \pm 0.10$ \\
\hline
\end{tabular}

sarcoma-bearing or the immunized mice showed negligible activities when the spleen cells were not stimulated with the tumor extract. On the contrary, the culture supernatants of spleen cells from these mice inhibited tumor-cell migration significantly $(\mathrm{P}<0.001)$, when the spleen cells were stimulated with the extract for either 2 or $24 \mathrm{hr}$. Although data are not shown in this table, the inhibition activity increased when spleen cells were enriched with T-lymphocytes and then stimulated with the sarcoma extract (MI-0.44 \pm 0.07 ). Spleen cells from normal mice did not show migration inhibition after incubating with the extract for $2 \mathrm{hr}$.

To know the specificity of the migration-inhibition factor produced by spleen cells of the sarcoma-bearing or -immunized mice stimulated in vitro with the tumor extract for $2 \mathrm{hr}$, the other types of target cells, theophylline-treated sarcoma cells, Ehrlich ascites tumor cells and guinea-pig macrophages were examined. Results are shown in Table II. The culture supernatants derived from the sarcomabearing or -immunized mice inhibited the migration of Ehrlich cells as well as sarcoma cells. On the other hand, they did not influence the migration of theophylline-treated sarcoma cells or guinea-pig macrophages.

A crude supernatant was chromatographed on a Sephadex G-100 column and eight fractions were isolated (Fig. 1). Inhibition effects against tumor-cell migration were found with the fractions of IV, V, VI and VII. The IVth and the Vth 


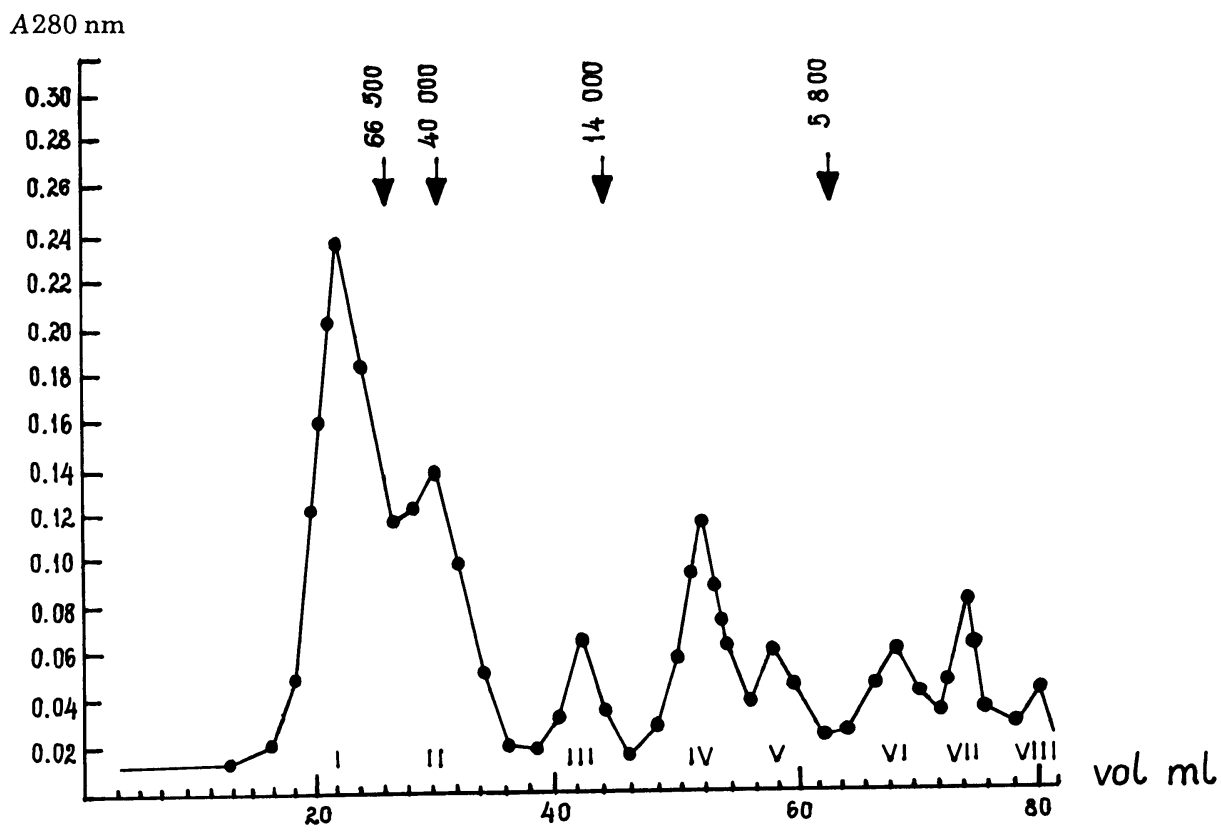

FRACTION NUMBER

Fig. 1. Crude supernatant fractionation on Sephadex G-100 columns. The positions of the calibrating molecular weight markers are indicated with arrows.

fractions were distributed in the range of mol. wt. between 14,000 and 5,800 daltons, and the VIth and the VIIth fractions were lower than 5,800 daltons. Peak inhibition of migration was found in fraction V. MI of target cells incubated with the fraction $\mathrm{V}$, obtained from the culture supernatant of spleen cells of the sarcoma-bearing mice stimulated with the sarcoma extract for $2 \mathrm{hr}$, was $0.60 \pm$ 0.05 against sarcoma cells, $0.57 \pm 0.05$ against Ehrlich cells, and $0.95 \pm 0.10$ against macrophages.

Variety of lymphoid cells existed in the smears prepared from sedimented spleen cell suspensions from the tumor-bearing mice. It was composed of $80.50 \pm$ $1.96 \%$ of small nonpyroninophilic lymphocytes with diameters of 5-6 $\mu \mathrm{m}, 4.30 \pm$ $0.09 \%$ of small pyroninophilic lymphocytes, $11.40 \pm 0.17 \%$ of medium-size lymphocytes $(7-10 \mu \mathrm{m})$ with pyroninophilic cytoplasm, $3.32 \pm 0.62 \%$ of large pyroninophilic blast cells $(12-15 \mu \mathrm{m})$, and $0.48 \pm 0.03 \%$ of plasmocytes.

Cells with ultrastructural features of T-lymphocytes (13) were found in the spleen cell suspensions including forms with numerous monoribosomes, vesicules, 
lysosome-like bodies as well as isolated profiles of the rough endoplasmic reticulum. The cell surface was irregular with microvilli. Large blast cells as well as plasmoblasts were also identified.

\section{DISCUSSION}

Our study showed that the splenic lymphoid cells of BALB/c mice which were transplanted sarcoma cells 20 days before or immunized with killed sarcoma cells 14 days before produced in the supernatants an active factor (lymphokine) which inhibited the migration of tumor cells of the sarcoma or of Ehrlich ascites, only when the splenic cells were incubated with a $3 \mathrm{M} \mathrm{KCl}$ extract of the sarcoma cells for 2 or $24 \mathrm{hr}$. The production of the inhibitory factor from the lymphoid cells could be accomplished within a brief time $(2 \mathrm{hr})$ of antigenic stimulation. This observation is agreed with the reports of lymphokine production after a short-time antigen stimulation $(14,15)$. Moreover, it was suggested that the tumor-associated antigen on the sarcoma cells could facilitate the release of the inhibitory factor from the immune splenic lymphoid cells. It could be suggested that the factor might be preliminarily elaborated in the spleen lymphocytes in vivo by stimulation of tumor antigen of the sarcoma, and that the activity of the factor might be potentiated by the antigen, like the antigen-dependent MIF $(16,17)$. However, the inhibiting factor differed from MIF, as it did not inhibit macrophage migration. In addition, the molecular weight of murine MIF was reported to be between 87,000 and 37,000 daltons (10), while our factor inhibiting tumor cell migration was lower than 14,000 daltons.

A similar factor inhibiting tumor-cell migration has already been obtained by stimulating the regional lymph node lymphocytes of the stomach cancer patients with gastric cancer extract (18).

Although data are not shown, the activity of the factor inhibiting tumor-cell migration was not lost by treatment with a protease inhibitor, Trasylol or Contrykal, or with a monosaccharide, $\alpha$-L-fucose or a-L-rhamnose

Our data indicated that migration of the sarcoma cells pretreated with $10^{-3} \mathrm{M}$ theophylline was not inhibited by the factor. The reason is unclear yet, but it might be possible that the tumor cell receptors for the inhibiting factor could be blocked by theophylline, which is an inhibitor of phosphodiesterase.

Further studies are needed, including those on clinical significance of the inhibitory factor of tumor-cell migration. 


\section{REFERENCES}

1. Cochran, A. J. (1971): Eur. J. Clin. Biol. Res., 16, 44-47.

2. Cochran, A. J., Kiessling, R., Klein, E., Gunven, P. and Foulis, A. K. (1973): J. Natl. Cancer Inst., 51, 1109-1111.

3. Cohen, M. C., Goss, A., Yoshida, T. and Cohen, S. (1978): J. Immunol., 121, 840-843.

4. Cohen, M. C. (1982): Cancer Res., 42, 2135-2138.

5. Donskoy, M, Forouhar, F. and Cohen, M. C. (1984): Cancer Res., 44, 38703872.

6. Julius, M. H., Simpson, E. and Herzenberg, L. A. (1973): Eur. J. Immunol., 3, 645-649.

7. Reisfeld, R. A., Pellegrin, M. A. and Kahan, B. D. (1971): Science, 172, 11341136.

8. Meltzer, M. S., Leonard, E. J., Rapp, H. J. and Borsos, T. (1971): J. Natl. Cancer Inst., 47, 703-709.

9. McCoy, J. L., Jerome, L. F., Dean, J. H., Cannon, G. B., Alford, T. C., Doering, T. and Herberman, R. B. (1974): J. Natl. Cancer Inst., 53, 11-17.

10. Kühner, A. L. and David, J. R. (1976): J. Immunol., 116, 140-145.

11. Limatibul, S., Shore, A., Dosch, H. M. and Gelfand, W. (1978): Clin. Exptl. Immunol., 33, 503-513.

12. Birch, R. E. and Polmar, S. H. (1981): Cell. Immunol., 57, 455-467.

13. Matter, A., Lisowska-Bernstein, B., Ryser, J. E., Lamelini, J.-P. and Vassali, P. (1972): J. Exptl. Med., 136, 1008-1030.

14. Rocklin, R. E., Bendzen, K. and Greineder, D. (1980): In H. G. Kunkel and F. J. Dixon [eds.], Advances in Immunology, Vol. 29, 55-136. Academic Press, New York.

15. Kotzsch, M., Grossmann, H., Irmscher, Y. and Miller, M. (1982): Exptl. Pathol., 21, 143-148.

16. Svejcar, J., Johanovsky and Pekárek, J. (1967): Allerg. Klinische Immunol., 133, 259-274.

17. Krejci, J., Pekárek, J., Rozprimova, L., Svejcar, J. and Johanovsky, J. (1976): Immunology, 31, 283-286.

18. Raichev, I. (1982): Scientific Works of the Higher Medical Institute, Pleven, Vol. I, Year IV, 69-74. 